\title{
Finite Element Analysis of Porosity Effects on Mechanical Properties for Tissue Engineering Scaffold
}

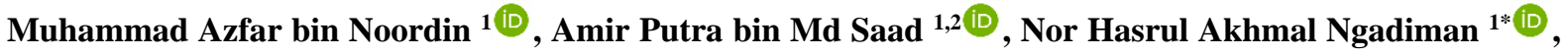 \\ Nur Syahirah Mustafa ${ }^{1}$ (D), Noordin bin Mohd Yusof ${ }^{1}$ (D), Azanizawati Ma'aram ${ }^{1}$ (D) \\ 1 School of Mechanical Engineering, Universiti Teknologi Malaysia, 81310 Johor Bahru, Johor, Malaysia; \\ mazfar25@graduate.utm.my (M.A.N.); norhasrul@utm.my (N.H.A.N.); nsyahirah83@graduate.utm.my (N.S.M.); \\ noordin@utm.my (N.M.Y.); azaniza@utm.my (A.M.); \\ 2 Medical Devices and Technology Centre (MEDITEC), Institute of Human Centred and Engineering (iHumEn), Universiti \\ Teknologi Malaysia (UTM), 81310 Johor Bahru, Johor, Malaysia; amirputra@utm.my; \\ * Correspondence: norhasrul@utm.my;
}

Scopus Author ID 55982418000

Received: 14.07.2020; Revised: 16.08.2020; Accepted: 17.08.2020; Published: 21.08.2020

\begin{abstract}
Porosity plays a vital role in the development of tissue engineering scaffolds. It influences the biocompatibility performance of the scaffolds by increasing cell proliferation and allowing the transportation of the nutrients, oxygen, and metabolites in the blood rapidly to generate new tissue structure. However, a high amount of porosity can reduce the mechanical properties of the scaffold. Thus, this study aims to determine the geometry of the porous structure of a scaffold which exhibits good mechanical properties while maintaining its porosity at a percentage of more than $80 \%$. Circle and square geometries were used since they are categorized as simple geometry. A unit cell of $12 \mathrm{~mm} x$ $12 \mathrm{~mm} \times 12 \mathrm{~mm}$ for square shape and pore area of $25 \pi \mathrm{mm}^{2}$ for circle shape was modeled and simulated by using Finite Element Analysis. The simulation consists of a compression test that determines which geometry exhibits better Young's Modulus. Since the circle geometry has better Young's Modulus, the pore size was furthered varied while maintaining the porosity of the scaffold to be above $80 \%$. The same method of the simulation was done on the models. The result shows that the smallest pore size model has the highest Young's Modulus, which still able to maintain the porosity at $80 \%$.
\end{abstract}

Keywords: Porosity, Finite Element Analysis, Tissue Engineering Scaffold, Young's Modulus.

(C) 2020 by the authors. This article is an open-access article distributed under the terms and conditions of the Creative Commons Attribution (CC BY) license (https://creativecommons.org/licenses/by/4.0/).

\section{Introduction}

Osteoporosis is raison d'être for the degeneration of the human bone. The impact of this disease leads to bone fracture. Hence, the current treatment proposed by orthopedic surgeons or medical practitioners is the use of tissue engineering (TE) bone scaffold [1]. The need for tissue engineering is very significant in regenerative medicine as it involves the replacement of a cell, tissue, or organ to retain its functionality [2].

Tissue engineering has been widely used in the development of bone scaffolds in which the bone scaffold will act as a medium for tissue formation $[3,4]$. The microarchitecture of the proposed bone scaffold must match with the real cancellous bone architecture to mimic the bone's functionality in terms of tissue formation and load-bearing. In the development of tissue engineering scaffold, biomaterials such as polymer, ceramic, metal, and composite have been widely used for tissue regeneration, especially for bone scaffold [5]. Among those types of 
biomaterials, polymers have shown great potential as the main materials for bone scaffold application specifically for tissue formation [6,7].

The major types of polymers that have been received a significant amount of attention in literature are Polylactic acid (PLA), Polyglycolic acid (PGA), Poly (lactic-co-glycolic acid) (PLGA), Poly $\varepsilon$-caprolactone (PCL), Polyethylene glycol (PEG), Polybutylene terephthalate (PBT) and Polyethylene terephthalate (PET) [6-9]. In fact, the brilliance of polymer is due to their biocompatibility with the human body in which the U.S. Food and Drug Administration (FDA) has approved the use of PLA in clinical applications [10,11]. However, the drawbacks of polymers are in terms of their mechanical properties relative to their metal, ceramic, and composite counterparts [12]. Despite that, certain polymers, such as PLA, have Young's Modulus of (0.3-4.14 GPa), which is close to Young's modulus of cancellous bone (0.01-2.0 GPa) [13]. It shows that PLA is a suitable material for the development of bone scaffolds [14$16]$.

The key factors that need to be considered before fabricating a bone scaffold are biocompatibility, biodegradability, mechanical properties, scaffold architecture, and manufacturing technology. Biocompatibility regarding scaffold is the ability of the scaffold to promote the normal cellular activity, including molecular signaling systems, without having adverse effects on the host tissue [17,18]. The porosity amount contributes to the biocompatibility performance of the scaffold. Any bone scaffold fabricated needs to have a porous structure to cater for cell proliferation and transportation of the nutrients, oxygen, and metabolites in the blood rapidly [19-21].

The architecture of the bone scaffold plays a significant role in enhancing the performance of the scaffold, both in mechanical properties and the regeneration of the cell or tissue [22]. Hence, this research focused on determining the shape of the porous structure that gives better mechanical strength to the scaffold. To enable the scaffold to be fabricated in mass production, the porous structure that is developed must not in the form of complicated shape.

Besides that, a scaffold that has a porosity of more than $80 \%$ is considered as high porosity and can increase the biocompatibility performance of the scaffold [23-25]. However, there are many studies that have been done in comparing the distinctive design of scaffold in terms of mechanical properties. Unfortunately, the designs compared do not have relatively the same porosity at more than $80 \%$ porosity [26-30]. Therefore, to address this gap, in this study, only square and circle shapes are being investigated for their mechanical properties where the porosity of both unit cell is relatively the same, at more than $80 \%$ porosity. In addition to that, this research will use the best pore shape to determine the relationship of the pore size with Young's modulus produce and, at the same time, maintaining the porosity of the scaffold at a percentage of more than $80 \%$ using finite element analysis.

\section{Materials and Method}

\subsection{Flow of method.}

First and foremost, the basic properties of PLA are determined. Next, the unit cell is characterized. Once the unit cell is characterized, the unit cell is analyzed by using finite element analysis via a compression test to find the optimal geometry at porosity more than $80 \%$. Subsequently, the optimal geometry is being chosen for further analysis in which the chosen unit cell will be developed into a scaffold with a porosity of more than $80 \%$, and the 
pore size will be varied in the scaffold. Finite element analysis will be done on each characterized scaffold to find the relation between pore size and Young's Modulus.

\subsection{Determination of basic properties of PLA.}

PLA is chosen as the material due to its availability and relatively low price. It can also be printed by an ordinary commercial 3D printer. The Young's Modulus of the PLA is determined by printing a solid PLA with a dimension of $12 \mathrm{~mm} \times 12 \mathrm{~mm} \times 12 \mathrm{~mm}$, and a compression test was executed on the solid PLA using a universal testing machine (The FastTrack 8874, Instron, Norwood, USA) at a strain rate of $0.005 / \mathrm{s}$ using $25 \mathrm{kN}$ load cell [31].

\subsection{Characterization of the unit cell.}

Table 1 shows the characterization of the unit cell of the scaffold.

\begin{tabular}{|c|c|c|c|}
\hline No. & Parameter & & \\
\hline 1 & Model Name & $\mathrm{C} 1$ & SQ1 \\
\hline 2 & Cell size & $\mathrm{L}=12, \mathrm{~d}=10$ & $\mathrm{~L}=12, \mathrm{l}=8.862$ \\
\hline 3 & Pore area $\left(\mathrm{mm}^{2}\right)$ & 78.54 & 78.54 \\
\hline 4 & $\begin{array}{l}\text { Porous volume, V } \\
\left(\mathrm{mm}^{3}\right)\end{array}$ & 1413.23 & 1435.35 \\
\hline 5 & $\begin{array}{l}\text { Surface area, SA } \\
\left(\mathrm{mm}^{2}\right)\end{array}$ & 675.22 & 726.46 \\
\hline 6 & Porosity (\%) & 81.8 & 83.1 \\
\hline
\end{tabular}

\subsection{Finite element analysis.}

Mesh independence test is done to make sure the simulation process has sufficient elements to solve the numerical analysis that has been set. This is done by repeating the simulation several times and, at the same time, increasing the number of elements until the results are converged. The model is compressed with a displacement of 5\% of its total height, and the bottom part of the model is fixed, as shown in Figure 1. The time of the period is set at $1 \mathrm{~s}$ with an increment of $0.01 \mathrm{~s}$.

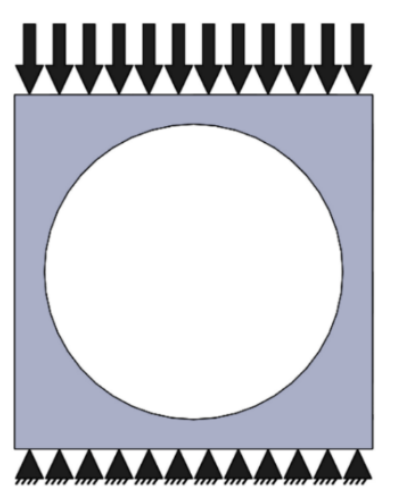

Figure 1. Boundary Condition of Model 


\subsection{Design of bone scaffold.}

The design of the bone scaffold is as shown in Table 2. The porosity is calculated using Equation 1 as follows:

$$
\text { Porosity }=(\text { Volume_porous/Volume_total }) \times 100 \%
$$

Table 2. Characterization of Circle Unit Circle with Various Pore Size

\begin{tabular}{|c|c|c|c|c|c|}
\hline \multirow[b]{2}{*}{ No. } & \multirow[b]{2}{*}{ Parameter } & & \\
\hline & & & & & \\
\hline 1 & Model name & $\mathrm{C} 1$ & C8 & C64 & C512 \\
\hline 2 & Cell size & $\mathrm{L}=12, \mathrm{~d}=10$ & $L=6, d=5$ & $\mathrm{~L}=3, \mathrm{~d}=2.5$ & $\mathrm{~L}=1.5, \mathrm{~d}=1.25$ \\
\hline 3 & $\begin{array}{l}\text { No. of cells in } \\
\text { each direction }\end{array}$ & 1 & 2 & 4 & 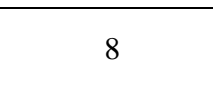 \\
\hline 4 & $\begin{array}{c}\text { Porous } \\
\text { Volume } \\
\left(\mathrm{mm}^{3}\right)\end{array}$ & 1413.23 & 1413.23 & 1413.23 & 1413.23 \\
\hline 5 & $\begin{array}{l}\text { Surface area } \\
\left(\mathrm{mm}^{2}\right)\end{array}$ & 675.22 & 957.67 & 1522.57 & 2652.37 \\
\hline 6 & SA/V ratio & 0.477785 & 0.677646 & 1.077369 & 1.876814 \\
\hline 7 & $\begin{array}{l}\text { Size of each } \\
\text { pore }(\mu \mathrm{m})\end{array}$ & 10000 & 5000 & 2500 & 1250 \\
\hline 8 & Porosity (\%) & 81.8 & 81.8 & 81.8 & 81.8 \\
\hline 9 & $\begin{array}{c}\text { Volume } \\
\text { enclosed } \\
\left(\mathrm{mm}^{3}\right)\end{array}$ & 1728 & 1728 & 1728 & 1728 \\
\hline
\end{tabular}

\section{Results and Discussion}

\subsection{Comparison of difference geometry.}

The von mises distribution is illustrated in Figure 2. The red arrow and yellow arrow in Figure 2 show the stress concentration of $\mathrm{C} 1$ and SQ1, respectively, when it is being compressed. It is important to identify the stress concentration of a structure as it can imply that the failure of structure will happen in that particular area if a failure occurs. From Figure 3 (a), the stress-strain curve of the $\mathrm{C} 1$ is steeper than the SQ1. This means that the $\mathrm{C} 1$ has a higher Young's modulus than the SQ1 as more stress is needed to stretch the circle hollow unit cell. The reason why the SQ1 has lower Young's modulus is due to their edgy geometry.
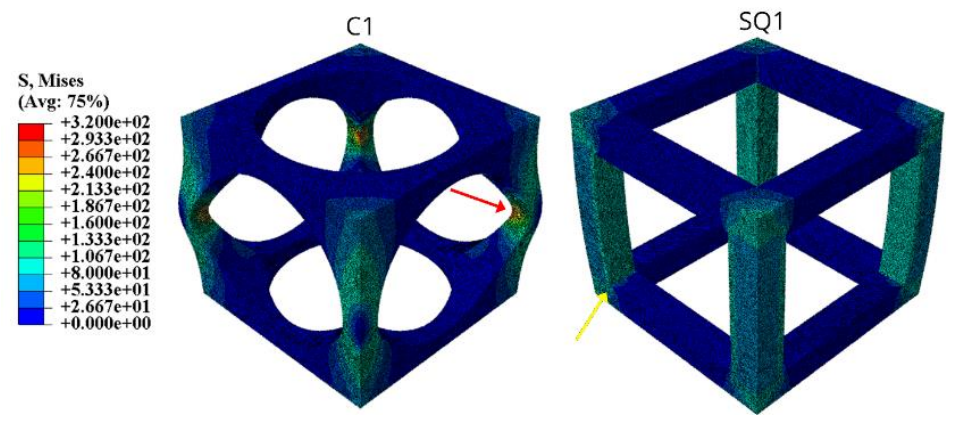

Figure 2. Von mises distribution of SQ1 and $\mathrm{C} 1$.

A sharp end will produce high concentration stress, which will make the unit cell has lower strength [32]. Figure 3 (b) will give better illustration related to the difference of Young's 
modulus of a square hollow unit cell and a circle hollow unit cell. Circle hollow unit cell has Young's modulus of 493.11 MPa while the square hollow unit cell has Young's modulus of 289.88 MPa. The value of Young's modulus produced in this present work is comparable with Sun et al., which got a Young's Modulus of $0.375 \mathrm{GPa}$ with a porosity of $83 \%$ with 4 square shape pore holes on each face of the PLA bone scaffold [33]. The small difference of the value of the Young's modulus is due to the different values of the surface area of both of the scaffold.

(a)

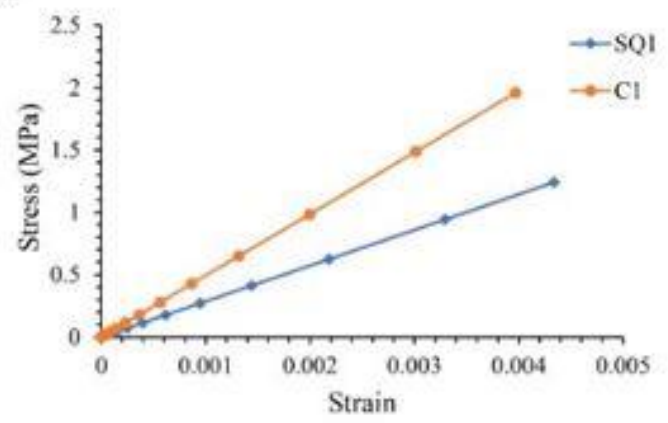

(b)

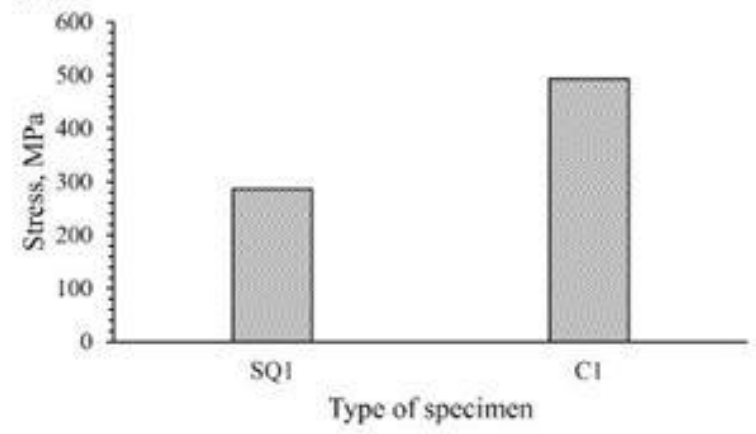

Figure 3. (a) Stress-strain Curve of SQ1 and C1 via Finite Element Analysis (b) Young's Modulus of SQ1 and $\mathrm{C} 1$

\subsection{Variation of pore size.}

After determining the best shape, which produces higher mechanical properties, the study continued to determine the relationship of pore size with the mechanical properties of the scaffold. C1, C8, C64, and C512, as shown in Figure 4, are simulated using Finite Element Analysis (FEA) as the circle hollow unit cell has superior Young's modulus relative to the square hollow unit cell. All the models $\mathrm{C} 1$ to $\mathrm{C} 512$ have a porosity of $81.8 \%$, and the main difference of all this model is their total surface area per volume ratio. From Table 2 and Figure 5 (a), as the surface area of the model increase, Young's modulus of the scaffold will increase. This means that model with higher surface area tends to resist the stress better in which more stress is needed to stretch it, which are in line with Pratap et al. [34].
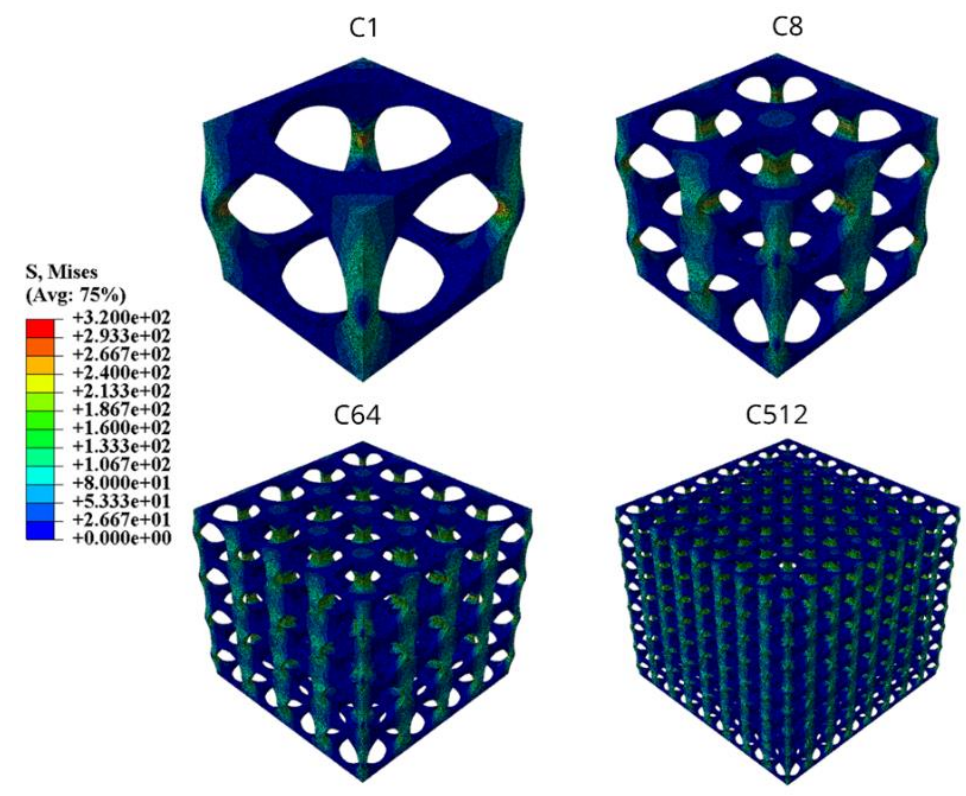

Figure 4. Von Mises Distribution of C1, C8, C64, and C512. 
Based on Figure 5 (b), Young's Modulus obtained for all models from C1 to C512 is within the cancellous bone range, which is the range of (0.01-2.0 GPa) [35]. In Fig. 5 (b), although the difference of value for surface area for C64 and C512 is significant, the difference of Young's modulus for C512 and C64 is small relative to the difference of value for C64 and $\mathrm{C} 8$ in terms of Young's Modulus. This is because all the models use the same material; hence there will be a point where there is a limit for enhancement of Young's modulus by varying the architecture of the models. C8 and C64, due to the large difference of the surface area with a value of $564.99 \mathrm{~mm}^{2}$ (about $60 \%$ percentage difference), contributes to the large difference of value in terms of Young's Modulus. On the other hand, the difference between Young's modulus of $\mathrm{C} 1$ and $\mathrm{C} 8$ is small due to the little difference of surface area with a value of $282.45 \mathrm{~mm}^{2}$ (about $40 \%$ percentage difference).

(a)

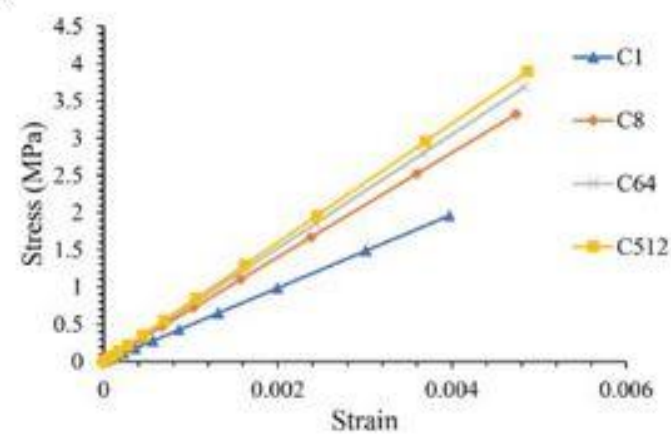

(b)

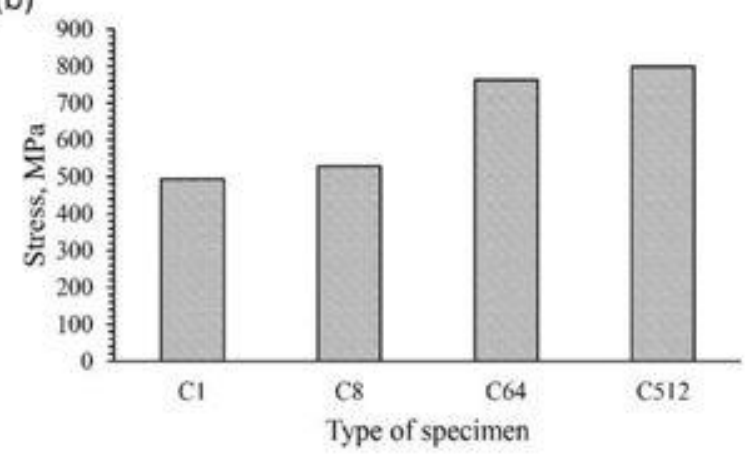

Figure 5. (a) Stress-strain curve of $\mathrm{C} 1, \mathrm{C} 8, \mathrm{C} 64$, and $\mathrm{C} 512$ under 5\% displacement (b) Bar chart of Young's modulus of $\mathrm{C} 1, \mathrm{C} 8, \mathrm{C} 64$, and $\mathrm{C} 512$.

\section{Conclusions}

The circle geometry porous structure is better in comparison to square geometry porous structure in terms of having higher Young's modulus. This statement is made after the circle hollow unit cell, and square hollow unit cell with the same area of hollowness are both compressed in a simulation. In addition to that, both unit cell has achieved mesh independent to make sure that the result produce is reliable. Hence, the circle geometry has been chosen as the porous structure in the scaffold that has been simulated. From four of the scaffolds $(\mathrm{C} 1, \mathrm{C} 8$, C64, and C512), it appears that C512 has the highest Young's modulus due to the highest surface area of C512 compared to other models. In conclusion, circle pore shape with the smallest pore size is a good combination to produce scaffold with high mechanical properties while providing a good porosity amount (80\%), which can enhance the biocompatibility properties of the developed scaffold section is not required.

\section{Funding}

This research was funded by the Ministry of Higher Education (MOHE), Universiti Teknologi Malaysia (UTM), and Research Management Centre, UTM, through Fundamental Research Grant Scheme (FRGS) funding number 5F188 and Collaborative Research Grant (CRG) funding number 08G22 \& 08G32.

\section{Acknowledgments}

Thank Universiti Teknologi Malaysia for the funding and provided facilities for this project 


\section{Conflicts of Interest}

The authors declare no conflict of interest.

\section{References}

1. $\quad$ Bagde, A.D.; Kuthe, A.M.; Quazi, S.; Gupta, V.; Jaiswal, S.; Jyothilal, S.; Lande, N.; Nagdeve, S. State of the Art Technology for Bone Tissue Engineering and Drug Delivery. IRBM 2019, 40, 133-144, doi:https://doi.org/10.1016/j.irbm.2019.03.001.

2. Li, H.; Shen, S.; Fu, H.; Wang, Z.; Li, X.; Sui, X.; Yuan, M.; Liu, S.; Wang, G.; Guo, Q. Immunomodulatory Functions of Mesenchymal Stem Cells in Tissue Engineering. Stem Cells International 2019, 2019, 9671206, doi:https://doi.org/10.1155/2019/9671206.

3. Dong, R.; Ma, P.X.; Guo, B. Conductive biomaterials for muscle tissue engineering. Biomaterials 2020, 229, 119584, doi:https://doi.org/10.1016/j.biomaterials.2019.119584.

4. Jeon, O.; Lee, Y.B.; Jeong, H.; Lee, S.J.; Wells, D.; Alsberg, E. Individual cell-only bioink and photocurable supporting medium for 3D printing and generation of engineered tissues with complex geometries. Mater. Horiz. 2019, 6, 1625-1631, doi:https://doi.org/10.1039/C9MH00375D.

5. Qu, H.; Fu, H.; Han, Z.; Sun, Y. Biomaterials for bone tissue engineering scaffolds: A review. RSC Advances 2019, 9, 26252-26262, doi:https://doi.org/10.1039/c9ra05214c.

6. Gregor, A.; Filová, E.; Novák, M.; Kronek, J.; Chlup, H.; Buzgo, M.; Blahnová, V.; Lukášová, V.; Bartoš, M.; Nečas, A., et al. Designing of PLA scaffolds for bone tissue replacement fabricated by ordinary commercial 3D printer. Journal of Biological Engineering 2017, 11, 1-21, doi:https://doi.org/10.1186/s13036-017-0074-3.

7. Singh, Y.P.; Moses, J.C.; Bhunia, B.K.; Nandi, S.K.; Mandal, B.B. Hierarchically structured seamless silk scaffolds for osteochondral interface tissue engineering. Journal of Materials Chemistry B 2018, 6 , 5671-5688, doi:https://doi.org/10.1039/C8TB01344F.

8. Toktam Ghassemi, A.S., Mohammad H. Ebrahimzadeh, Alireza Mousavian, Jebraeel Movaffagh, Ali Moradi. Current Concepts in Scaffolding for Bone Tissue Engineering. The Archives of Bone and Joint Surgery (ABJS) 2018, 6, 90-99.

9. $\quad$ Kashte, S.; Kochrekar, S.; Sharma, R.K.; Kadam, S. Layer By Layer Deposited Osteoinductive Scaffolds for Bone Tissue Engineering. Letters in Applied NanoBioScience 2020, 9, 1089-1098, doi:https://doi.org/10.33263/LIANBS92.10891098.

10. Qi, F.; Wu, J.; Li, H.; Ma, G. Recent research and development of PLGA/PLA microspheres/nanoparticles: A review in scientific and industrial aspects. Frontiers of Chemical Science and Engineering 2019, 13, 14-27, doi:https://doi.org/10.1007/s11705-018-1729-4.

11. Milovanovic, S.; Markovic, D.; Mrakovic, A.; Kuska, R.; Zizovic, I.; Frerich, S.; Ivanovic, J. Supercritical CO2 - assisted production of PLA and PLGA foams for controlled thymol release. Materials Science and Engineering: $C \quad$ 2019, doi:https://doi.org/10.1016/j.msec.2019.01.106.

12. Mondal, S.; Pal, U. 3D hydroxyapatite scaffold for bone regeneration and local drug delivery applications. Journal of Drug Delivery Science and Technology 2019, 53, 101131, doi:https://doi.org/10.1016/j.jddst.2019.101131.

13. Kashirina, A.; Yao, Y.; Liu, Y.; Leng, J. Biopolymers as bone substitutes: a review. Biomater. Sci. 2019, 7, 3961-3983, doi:https://doi.org/10.1039/C9BM00664H.

14. Martin, V.; Ribeiro, I.A.; Alves, M.M.; Gonçalves, L.; Claudio, R.A.; Grenho, L.; Fernandes, M.H.; Gomes, P.; Santos, C.F.; Bettencourt, A.F. Engineering a multifunctional 3D-printed PLA-collagenminocycline-nanoHydroxyapatite scaffold with combined antimicrobial and osteogenic effects for bone regeneration. Materials Science and Engineering: $C$ 2019, 101, 15-26, doi:https://doi.org/10.1016/j.msec.2019.03.056.

15. Chen, X.; Gao, C.; Jiang, J.; Wu, Y.; Zhu, P.; Chen, G. 3D printed porous PLA/nHA composite scaffolds with enhanced osteogenesis and osteoconductivity in vivo for bone regeneration. Biomedical Materials 2019, 14, doi:https://doi.org/10.1088/1748-605X/ab388d.

16. Farah, S.; Anderson, D.G.; Langer, R. Physical and mechanical properties of PLA, and their functions in widespread applications - A comprehensive review. Advanced Drug Delivery Reviews 2016, 107, 367392, doi:https://doi.org/10.1016/j.addr.2016.06.012.

17. Moreno Madrid, A.P.; Vrech, S.M.; Sanchez, M.A.; Rodriguez, A.P. Advances in additive manufacturing for bone tissue engineering scaffolds. Materials Science and Engineering: C 2019, 100, 631-644, doi:https://doi.org/10.1016/j.msec.2019.03.037.

18. Kazimierczak, P.; Benko, A.; Nocun, M.; Przekora, A. Novel chitosan/agarose/hydroxyapatite nanocomposite scaffold for bone tissue engineering applications: comprehensive evaluation of biocompatibility and osteoinductivity with the use of osteoblasts and mesenchymal stem cells. International journal of nanomedicine 2019, 14, 6615-6630, doi:https://doi.org/10.2147/IJN.S217245. 
19. Carluccio, D.; Xu, C.; Venezuela, J.; Cao, Y.; Kent, D.; Bermingham, M.; Demir, A.G.; Previtali, B.; Ye, Q.; Dargusch, M. Additively manufactured iron-manganese for biodegradable porous load-bearing bone scaffold applications. Acta Biomaterialia 2020, 103, 346-360, doi:https://doi.org/10.1016/j.actbio.2019.12.018.

20. Chen, Z.; Yan, X.; Yin, S.; Liu, L.; Liu, X.; Zhao, G.; Ma, W.; Qi, W.; Ren, Z.; Liao, H., et al. Influence of the pore size and porosity of selective laser melted Ti6A14V ELI porous scaffold on cell proliferation, osteogenesis and bone ingrowth. Materials Science and Engineering: C 2020, 106, 110289, doi:https://doi.org/10.1016/j.msec.2019.110289.

21. Ngadiman, N.H.A.; Noordin, M.Y.; Idris, A.; Kurniawan, D. A review of evolution of electrospun tissue engineering scaffold: From two dimensions to three dimensions. Proceedings of the Institution of Mechanical Engineers, Part H: Journal of Engineering in Medicine 2017, 231, 597-616, doi:https://doi.org/10.1177/0954411917699021.

22. Zhao, H.; Li, L.; Ding, S.; Liu, C.; Ai, J. Effect of porous structure and pore size on mechanical strength of 3D-printed comby scaffolds. Materials Letters 2018, 223, 21-24, doi:https://doi.org/10.1016/j.matlet.2018.03.205.

23. Ngadiman, N.H.A.; Mohd, N.; Idris, A.; Misran, E.; Kurniawan, D. Development of highly porous biodegradable $\gamma$-Fe 203 / polyvinyl alcohol nano fi ber mats using electrospinning process for biomedical application. Materials Science \& Engineering $C$ 2017, 70, 520-534, doi:https://doi.org/10.1016/j.msec.2016.09.002.

24. Ali, D.; Ozalp, M.; Blanquer, S.B.G.; Onel, S. Permeability and fluid flow-induced wall shear stress in bone scaffolds with TPMS and lattice architectures: A CFD analysis. European Journal of Mechanics B/Fluids 2020, 79, 376-385, doi:https://doi.org/10.1016/j.euromechflu.2019.09.015.

25. Wang, S.; Liu, L.; Li, K.; Zhu, L.; Chen, J.; Hao, Y. Pore functionally graded Ti6Al4V scaffolds for bone tissue engineering application. Materials \& Design 2019, 168, 107643, doi:https://doi.org/10.1016/j.matdes.2019.107643.

26. Ali, D.; Sen, S. Finite Element Analysis of Mechanical Behavior, Permeability and Fluid Induced Wall Shear Stress of High Porosity Scaffolds with Gyroid and Lattice-Based Architectures. Journal of the Mechanical Behavior of Biomedical Materials 2017, 75, 262-270, doi:https://doi.org/10.1016/j.jmbbm.2017.07.035.

27. Li, S.; Kim, Y.-w.; Choi, M.-s.; Nam, T.-h. Superelastic Ti-18Zr-12.5Nb-2Sn (at.\%) alloy scaffolds with high porosity fabricated by fiber metallurgy for biomedical applications. Intermetallics 2019, 115, 106631, doi:https://doi.org/10.1016/j.intermet.2019.106631.

28. Restrepo, S.; Ocampo, S.; Ramírez, J.A.; Paucar, C.; García, C. Mechanical properties of ceramic structures based on Triply Periodic Minimal Surface ( TPMS ) processed by 3D printing Mechanical properties of ceramic structures based on Triply Periodic Minimal Surface (TPMS) processed by 3D printing. Journal of Physics: Conference Series 2017, 935, doi:https://doi.org/10.1088/17426596/935/1/012036.

29. Montazerian, H.; Davoodi, E.; Asadi-eydivand, M.; Kadkhodapour, J.; Solati-hashjin, M. Materials \& Design Porous scaffold internal architecture design based on minimal surfaces : A compromise between permeability and elastic properties. Materials \& Design 2017, 126, 98-114, doi:https://doi.org/10.1016/j.matdes.2017.04.009.

30. Zhao, L.; Pei, X.; Jiang, L.; Hu, C.; Sun, J.; Xing, F.; Zhou, C.; Fan, Y.; Zhang, X. Bionic design and 3D printing of porous titanium alloy scaffolds for bone tissue repair. Composites Part B: Engineering 2019, 162, 154-161, doi:https://doi.org/10.1016/j.compositesb.2018.10.094.

31. Md. Saad, A.P.; Jasmawati, N.; Harun, M.N.; Abdul Kadir, M.R.; Nur, H.; Hermawan, H.; Syahrom, A. Dynamic degradation of porous magnesium under a simulated environment of human cancellous bone. Corrosion Science 2016, 112, 495-506, doi:https://doi.org/10.1016/j.corsci.2016.08.017.

32. Tang, M.S.; Kadir, A.Z.A.; Ngadiman, N.H.A. Simulation analysis of different bone scaffold porous structures for fused deposition modelling fabrication process. \{IOP\} Conference Series: Materials Science and Engineering 2020, 788, 12023, doi:https://doi.org/10.1088/1757-899x/788/1/012023.

33. Sun, W.; Starly, B.; Nam, J.; Darling, A. Bio-CAD modeling and its applications in computer-aided tissue engineering. Computer-aided Design 2005, 37, 1097-1114, doi:https://doi.org/10.1016/j.cad.2005.02.002.

34. Pratap, S.; Bhardwaj, T.; Shukla, M. Lattice Modeling and Finite Element Simulation for Additive Manufacturing of Porous Scaffolds. In IEEE International Conference on Advances in Mechanical, Industrial, Automation and Management Systems (AMIAMS 2017), IEEE: Allahabad, India, 2017; https://doi.org/10.1109/AMIAMS.2017.8069234pp 333-336.

35. Geetha, M.; Singh, A.K.; Asokamani, R.; Gogia, A.K. Ti based biomaterials , the ultimate choice for orthopaedic implants - A review. Progress in Materials Science 2009, 54, 397-425, doi:https://doi.org/10.1016/j.pmatsci.2008.06.004. 